beginning of an era of intensive research culminating in modern discharge lamps. Among these, the xenon arc, which has so far been confined to laboratory demonstrations, is exhibited, together with microsecond flash tubes and compact source lamps. The history of fluorescence is covered by an attractive series of demonstrations, and its applications, including that of mine lighting, are also shown. Applications of lighting to the theatre, television, roads and medical uses include many interesting demonstrations, while good lighting in the home is shown by a full-scale sequence exhibit called the "Room of To-morrow". The Exhibition will remain open until the end of September.

\section{Davy Faraday Exhibition in Paris}

AN exhibition devoted to the life and work of Davy and Faraday has been arranged at the Palais de la Découverte in Paris (which operates in association with the University of Paris) with the close collaboration and support of the Royal Institution, the Institution of Electrical Engineers, and the Science Museum, and will remain open until July. The managers of the Royal Institution have lent a number of the relics of Michael Faraday from their collection, as, for example, some of the original apparatus used by him in his experiments and pieces of his laboratory and office equipment. The Council of the Institution of Electrical Engineers has lent a number of Faraday manuscripts and letters and the full-sized reproduction of the statue of Faraday, the original of which stands on the main staircase in the Royal Institution, which dominated the Faraday Centenary Exhibition at the Albert Hall, London, in 1931. The General Post Office has provided an ingenious working section of an automatic telephone exchange, recently shown at Radiolympia. With the collaboration of the British Council, arrangements have been made for a number of lectures to be delivered at the Exhibition by British men of science and engineers on the life and work of Davy and Faraday.

\section{British Institute of Management}

Presiding at the first meeting of the British Institute of Management on April 21, Sir Charles Renold, chairman of the Institute, said that the Institute would need the goodwill, active interest and co-operation of all who exercised the major responsibilities of management. Management, he emphasized, is not concerned with party politics or with theories of ownership, and it is with the principles which apply to all industries and with the problems arising in their application that the Institute is concerned. A national drive for better management would be developed along three main lines : by the compilation of knowledge about management; by promoting education and training facilities; and by the dissemination of knowledge about management. Speaking of the necessary research, Sir Charles hopes that the Institute will have the co-operation of the univers. ities and other bodies, including the trade unions, and he pointed out that there is little or no guiding experience in Great Britain for some of the problems of management presented by the vast scale of some of the nationalized industries. The Institute has already initiated discussions with university authorities on the preparation at the university-level of men for management, and is also studying training for foremen and supervisors. Sir Stafford Cripps, who, as well as Sir Frederick Bain and Miss Florence Hancock, chairman of the Trades Union Congress, also spoke, emphasized the importance of the Institute being wholly free from Government interference and from concern with party politics. While providing a grant-in-aid, the Government is in no way attempting to control expenditure within the broad purposes agreed. The failure of so many production units to attain the high standards of efficiency set by the most skilled and enlightened managements is a cause of many of the present economic difficulties of Britain; but in spite of the great importance of the technical side, the first and overriding requirement is the creation of an atmosphere of trust. Only in that atmosphere can we secure the co-operation of those working in the factories in the difficult adjustments which the new techniques of production often involve.

\section{British Association : Brighton Meeting}

The British Association has now issued a preliminary programme of the annual meeting to be held in Brighton during September 8-15, with Sir Henry Tizard as president. At Dundee last year 3,300 people attended the first of the annual meetings to be held after the outbreak of war in 1939, and the theme of the meeting was the conversion of science from the destructive uses of war to the constructive uses of peace. The programme for the Brighton meeting is again topical and of wide general interest. Among the topics to be discussed are : achievements of X-ray analysis; newer metals and alloys in industry; geology to-day and to-morrow; biology in schools; Colonial development; movements of population in the Commonwealth; the metric system; building materials; human blood groups; colour vision; changing aspects of nutrition; selection of university students ; problems of old age ; aspects of world education; administrator and teacher ; maintenance of world food supply ; forestry and the community. The programme can be obtained from the Secretary of the Association, Burlington House, Piccadilly, London, W.1.

The presidents of the various sections are as follow : (A) Mathematics and Physics : Sir Lawrence Bragg; (B) Chemistry : Prof. John Read; (C) Geology : Dr. A. E. Trueman; (D) Zoology : Prof. H. Graham Cannon; (E) Geography : Lord Rennell of Rodd; (F) Economics : Sir Hubert Henderson; (G) Engineering : Prof. T. R. Cave-Browne-Cave; (H) Anthropology and Archceology : Mr. R. U. Sayce; (I) Physio. logy: Prof. H. Hartridge; (J) Psychology : Prof. A. Rex Knight; (K) Botany : Prof. J. R. Matthews ; (L) Education: Mr. O. Lester Smith; (M) Agriculture: Dr. G. Scott Robertson; Conference of Delegates of Corresponding Societies : Prof. H. J. Fleure.

\section{Colonial Microbiological Research Institute, Trinidad}

ACTING on a recommendation of Sir Robert Robinson and Prof. J. L. Simonsen, who paid a visit to the Caribbean in 1944, the Colonial Products Research Council decided to erect in Port of Spain, Trinidad, a Colonial Microbiological Research Institute. This Institute, of which Dr. A. C. Thaysen, formerly of the Chemical Research Laboratory, Teddington, is the director, will be opened officially on July 5 by Lord Hankey, chairman of the Colonial Products Research Council. Invitations to attend the opening have been sent to Canada, the United States, the Caribbean Commission, and to a number of South American Republics. The opening will be followed on the Tuesday and Wednesday by scientific meetings. 